\title{
Greenhouse gas production in degrading ice-rich permafrost deposits in northeastern Siberia
}

\author{
Josefine Walz ${ }^{1,2}$, Christian Knoblauch ${ }^{1,2}$, Ronja Tigges ${ }^{1}$, Thomas Opel ${ }^{3,4}$, Lutz Schirrmeister ${ }^{4}$, and \\ Eva-Maria Pfeiffer ${ }^{1,2}$ \\ ${ }^{1}$ Institute of Soil Science, Universität Hamburg, 20146 Hamburg, Germany \\ ${ }^{2}$ Center for Earth System Research and Sustainability, Universität Hamburg, 20146 Hamburg, Germany \\ ${ }^{3}$ Permafrost Laboratory, Department of Geography, University of Sussex, Brighton, BN1 9RH, UK \\ ${ }^{4}$ Alfred Wegener Institute Helmholtz Centre for Polar and Marine Research, 14473 Potsdam, Germany
}

Correspondence: Josefine Walz (josefine.walz@uni-hamburg.de)

Received: 7 May 2018 - Discussion started: 14 May 2018

Revised: 14 August 2018 - Accepted: 21 August 2018 - Published: 13 September 2018

\begin{abstract}
Permafrost deposits have been a sink for atmospheric carbon for millennia. Thaw-erosional processes, however, can lead to rapid degradation of ice-rich permafrost and the release of substantial amounts of organic carbon (OC). The amount of the OC stored in these deposits and their potential to be microbially decomposed to the greenhouse gases carbon dioxide $\left(\mathrm{CO}_{2}\right)$ and methane $\left(\mathrm{CH}_{4}\right)$ depends on climatic and environmental conditions during deposition and the decomposition history before incorporation into the permafrost. Here, we examine potential greenhouse gas production as a result of degrading ice-rich permafrost deposits from three locations in the northeastern Siberian Laptev Sea region. The deposits span a period of about $55 \mathrm{kyr}$ from the last glacial period and Holocene interglacial. Samples from all three locations were incubated under aerobic and anaerobic conditions for 134 days at $4{ }^{\circ} \mathrm{C}$. Greenhouse gas production was generally higher in deposits from glacial periods, where $0.2 \%-6.1 \%$ of the initially available OC was decomposed to $\mathrm{CO}_{2}$. In contrast, only $0.1 \%-4.0 \%$ of initial OC was decomposed in permafrost deposits from the Holocene and the late glacial transition. Within the deposits from the Kargin interstadial period (Marine Isotope Stage 3), local depositional environments, especially soil moisture, also affected the preservation of OC. Sediments deposited under wet conditions contained more labile OC and thus produced more greenhouse gases than sediments deposited under drier conditions. To assess the greenhouse gas production potentials over longer periods, deposits from two locations were incubated for a total of 785 days. However, more than
\end{abstract}

$50 \%$ of total $\mathrm{CO}_{2}$ production over 785 days occurred within the first 134 days under aerobic conditions, while $80 \%$ were produced over the same period under anaerobic conditions, which emphasizes the nonlinearity of the OC decomposition processes. Methanogenesis was generally observed in active layer samples but only sporadically in permafrost samples and was several orders of magnitude smaller than $\mathrm{CO}_{2}$ production.

\section{Introduction}

Permafrost, i.e., ground that is at or below $0{ }^{\circ} \mathrm{C}$ for at least two consecutive years (van Everdingen, 2005), may preserve organic matter (OM) for millennia (Ping et al., 2015). The current organic carbon (OC) pool of soils, refrozen thermokarst, and Holocene cover deposits in the top $3 \mathrm{~m}$ as well as sediments and deltaic deposits below $3 \mathrm{~m}$ in permafrost landscapes is estimated to be about $1300 \mathrm{Pg}$, of which about $800 \mathrm{Pg}$ are perennially frozen (Hugelius et al., 2014). However, warming-induced environmental changes and permafrost degradation could lead to rapid thawing of substantial amounts of currently frozen OM, microbial decomposition of the thawed OM, and rising greenhouse gas fluxes to the atmosphere (Natali et al., 2015; Schuur et al., 2015). The effects of elevated atmospheric greenhouse gas concentrations and temperatures on processes in soils and sediments are expected to be most pronounced in nearsurface layers (Schneider von Deimling et al., 2012). How- 
ever, thermo-erosion of ice-rich permafrost, i.e., permafrost with more than $20 \mathrm{vol} \%$ ice (Brown et al., 1998), also enables deep thawing of several tens of meters (Schneider von Deimling et al., 2015).

Ice-rich permafrost deposits, also called ice complex deposits, accumulated in unglaciated Arctic lowlands. During cold stages, fine-grained organic-rich material of polygenetic origin was deposited on predominantly flat plains (Schirrmeister et al., 2013). The deposits are dissected by large ice wedges, which can amount for up to $60 \mathrm{vol} \%$ (Ulrich et al., 2014). The most prominent ice complex deposits, referred to as yedoma, accumulated during the late Pleistocene between approximately 55 and $13 \mathrm{ka}$ before present (BP), i.e., during the Marine Isotope Stages (MIS) 3 and 2 (Schirrmeister et al., 2011). Age-depth correlations, however, indicate that at some locations the accumulation of yedoma material may have already started between 80 and $60 \mathrm{kaBP}$, i.e., during MIS 4 (Schirrmeister et al., 2002b). Locally, remnants of older ice complex deposits of both late MIS 7-early MIS 6 and MIS 5 age are also preserved (Schirrmeister et al., 2002a; Wetterich et al., 2016; Opel et al., 2017), but not studied yet in terms of greenhouse gas production.

The thickness of yedoma deposits in Siberia (Grosse et al., 2013) and Alaska (Kanevskiy et al., 2011) can reach more than $50 \mathrm{~m}$. At the time of deposition, rapid sedimentation and freezing incorporated relatively undecomposed $\mathrm{OM}$ into the permafrost (Strauss et al., 2017). However, owing to the high ice content, yedoma deposits are highly susceptible to warming-induced environmental changes, erosion, and ground subsidence following permafrost thaw (e.g., Morgenstern et al., 2013). Only $30 \%$ of the yedoma region (about $416000 \mathrm{~km}^{2}$ ) is considered intact, while the other $70 \%$ has already undergone some level of permafrost degradation (Strauss et al., 2013). Today, the whole yedoma domain stores $213-456 \mathrm{Pg}$ of OC, of which $83-269 \mathrm{Pg}$ is stored in intact yedoma and $169-240 \mathrm{Pg}$ in thermokarst and refrozen taberal deposits (Zimov et al., 2006; Strauss et al., 2013, 2017; Hugelius et al., 2014; Walter Anthony et al., 2014). For an about $88000 \mathrm{~km}^{2}$ area along the Bolshaya Chukochya and Alazeya River basins and the eastern parts of the Yana-Indigirka and Kolyma lowlands in northeastern Siberia, Shmelev et al. (2017) estimate the size of the total carbon pool in the upper $25 \mathrm{~m}$ to be $31.2 \mathrm{Pg}$, of which 3.7 Pg is stored in yedoma deposits. However, high spatial and temporal variability results in large uncertainties about how much OC will be exposed by degradation of ice-rich permafrost and how much of this OC can be microbially decomposed to the greenhouse gases carbon dioxide $\left(\mathrm{CO}_{2}\right)$ or methane $\left(\mathrm{CH}_{4}\right)$ after thaw.

In addition to the quantity of $\mathrm{OC}$, its decomposability will influence how fast the OC in permafrost deposits can be transformed into $\mathrm{CO}_{2}$ or $\mathrm{CH}_{4}$ after thaw (MacDougall and Knutti, 2016; Knoblauch et al., 2018). Since plants are the main source of OM in soils, vegetation composition plays an important role for OM decomposability (Iversen et al., 2015). Furthermore, OM has undergone different degradation processes before being incorporated into permafrost depending on permafrost formation pathways (Waldrop et al., 2010; Harden et al., 2012). In epigenetic permafrost, that is permafrost aggradation through intermittent freezing after the material was deposited, OM has already undergone some level of transformation, and easily decomposable, labile OC compounds are decomposed and lost to the atmosphere prior to incorporation into the permafrost (Hugelius et al., 2012). In contrast, $\mathrm{OM}$ in syngenetically frozen yedoma, i.e., concurrent material deposition and permafrost aggradation, had little time to be transformed prior to freezing and may thus contain high amounts of labile OC, which may be quickly decomposed to greenhouse gases after thawing (Dutta et al., 2006). In this case, the amount and decomposability of the fossil $\mathrm{OM}$ is controlled by the OM source, i.e., predominantly vegetation, which in turn depends on paleoclimatic conditions (Andreev et al., 2011).

The decomposability of permafrost $\mathrm{OM}$ is often assessed based on OM degradation proxies, total OC (TOC) content, ratios of total organic carbon to total nitrogen $(\mathrm{C} / \mathrm{N})$, or stable carbon isotopes $\left(\delta^{13} \mathrm{C}_{\mathrm{org}}\right)$ with contradictory results (Strauss et al., 2015; Weiss et al., 2016). Only few studies have measured $\mathrm{CO}_{2}$ and $\mathrm{CH}_{4}$ production potentials from Siberian yedoma deposits under laboratory conditions (Dutta et al., 2006; Zimov et al., 2006; Lee et al., 2012; Knoblauch et al., 2013, 2018). In this study, we present incubation data from late Pleistocene yedoma and Holocene interglacial deposits from three locations in northeastern Siberia. We hypothesize that OM deposited during glacial periods experienced little prefreezing transformation and thus provides a more suitable substrate for future microbial decomposition and post-thawing greenhouse gas production than Holocene deposits.

\section{Study region and sample material}

Three locations in the Laptev Sea region in northeastern Siberia were studied (Fig. 1). The whole region is underlain by continuous permafrost reaching depths of 450$700 \mathrm{~m}$ onshore and $200-600 \mathrm{~m}$ offshore (Romanovskii et al., 2004), with ground temperatures of $-11^{\circ} \mathrm{C}$ for terrestrial permafrost (Drozdov et al., 2005) and $-1{ }^{\circ} \mathrm{C}$ for submarine permafrost (Overduin et al., 2015). Long, cold winters and short, cool summers characterize the current climate. Mean annual (1971-2000) temperatures and precipitation sums are $-13.3^{\circ} \mathrm{C}$ and $266 \mathrm{~mm}$ at the central Laptev Sea coast (Tiksi, WMO station 21824) and $-14.9^{\circ} \mathrm{C}$ and $145 \mathrm{~mm}$ in the eastern Laptev Sea region (Mys Shalaurova, WMO station 21647, Bulygina and Razuvaev, 2012). Modern vegetation cover is dominated by erect dwarf shrub and in places by sedge, moss, low-shrub wetland vegetation or tussock sedge, dwarf shrub, or moss tundra vegetation (CAVM Team, 2003). 


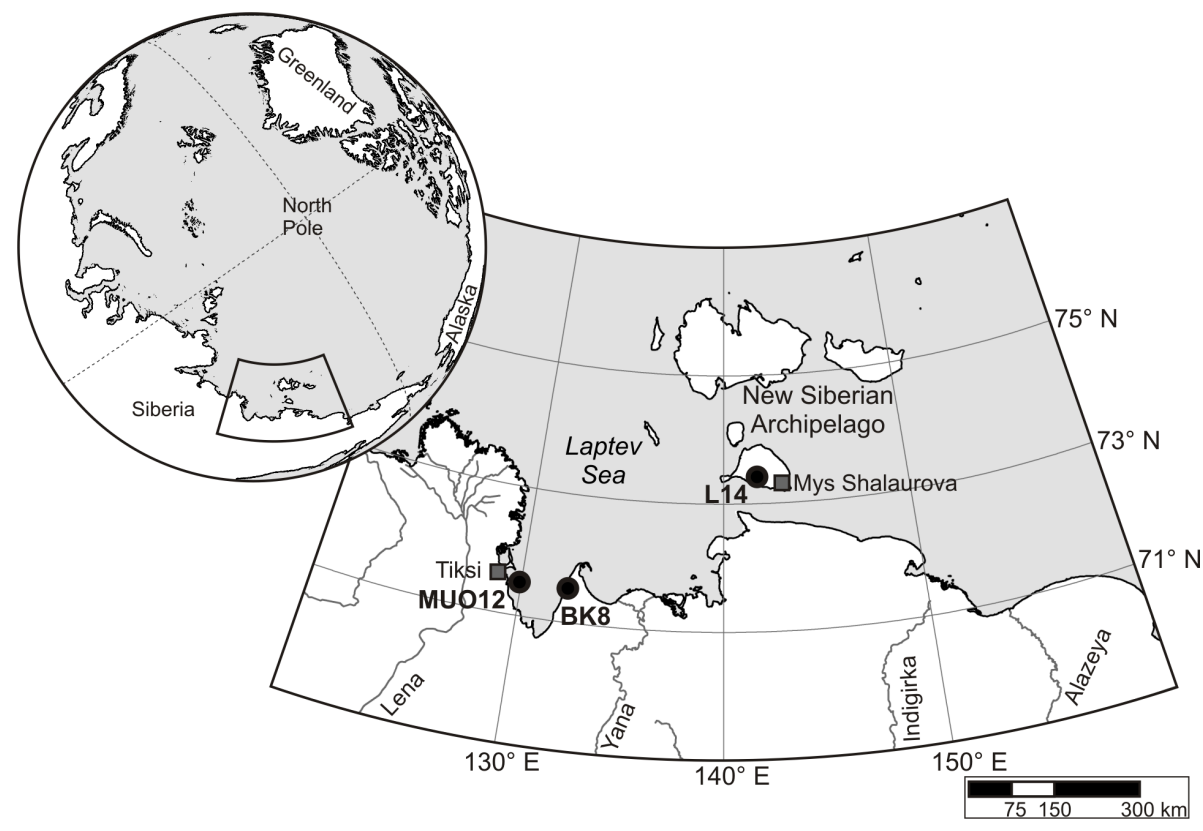

Figure 1. Overview of the Laptev Sea region with the study locations at Muostakh Island (sample code MUO12), the Buor Khaya Peninsula (BK8) and Bol'shoy Lyakhovsky Island (L14).

A compilation of the regional stratigraphic scheme used in this work with paleoclimate and vegetation history is summarized in Table 1.

The first study location is on Muostakh Island $\left(71.61^{\circ} \mathrm{N}\right.$, $129.96^{\circ} \mathrm{E}$ ), an island in the Buor Khaya Bay $40 \mathrm{~km}$ east of Tiksi. Between 1951 and 2013, the area and volume of Muostakh Island, which is subject to major coastal erosion (up to $-17 \mathrm{~m} \mathrm{a}^{-1}$ ) and thaw subsidence, decreased by $24 \%$ and $40 \%$, respectively (Günther et al., 2015). The entire sedimentary sequence of Muostakh Island (sample code MUO12) was sampled in three vertical subprofiles on the northeastern shore (Meyer et al., 2015). In the current study, we used 14 sediment samples from the entire MUO12 sequence between 0.5 and $15.6 \mathrm{~m}$ b.s. (meters below surface), which corresponds to 19.5 and $4.4 \mathrm{~m}$ a.s.l. (meters above sea level).

The second study location is on the Buor Khaya Peninsula $\left(71.42^{\circ} \mathrm{N}, 132.11^{\circ} \mathrm{E}\right)$. Thermokarst processes affect $85 \%$ of the region, which resulted in more than $20 \mathrm{~m}$ of permafrost subsidence in some areas (Günther et al., 2013). Long-term (1969-2010) coastal erosion rates along the western coast of the Buor Khaya Peninsula are about $-1 \mathrm{ma}^{-1}$ (Günther et al., 2013). On top of the yedoma hill, approximately $100 \mathrm{~m}$ from the cliff edge, a $19.8 \mathrm{~m}$ long permafrost core (sample code BK8) was drilled (Grigoriev et al., 2013). Detailed cryolithological, geochemical, and geochronological data (Schirrmeister et al., 2017); palynological analysis (Zimmermann et al., 2017b); and lipid biomarker studies (Stapel et al., 2016) were previously published for the BK8 site. In the current study, 20 sediment samples spread evenly between the surface and $19.8 \mathrm{~m}$ b.s. (or 34 and $14.2 \mathrm{~m}$ a.s.1.) were analyzed, excluding an ice wedge between 3.2 and $8.5 \mathrm{~m}$ b.s.

The third sampling location is on Bol'shoy Lyakhovsky Island $\left(73.34^{\circ} \mathrm{N} ; 141.33^{\circ} \mathrm{E}\right)$, the southernmost island of the New Siberian Archipelago. Four cores (sample code L14) were drilled on the southern coast (Schwamborn and Schirrmeister, 2015). Core descriptions, geochronological data, and pollen and plant DNA analyses can be found in Zimmermann et al. (2017a), while biomarkers and pore water analysis are reported in Stapel et al. (2018). Based on previous stratigraphic studies from this location (e.g., Andreev et al., 2009; Wetterich et al., 2009, 2014) we focused on two cores, which represent the MIS 1-MIS 3 period investigated here. The first core, L14-05, was recovered from inside a thermokarst basin, $4 \mathrm{~km}$ west of the Zimov'e River mouth, with Holocene thermokarst deposits overlying thawed and refrozen taberal yedoma deposits (Wetterich et al., 2009). Five sediment samples between 0 and $7.9 \mathrm{mb}$ b.s. (11.5 and $3.6 \mathrm{~m}$ a.s.1.) were analyzed for the current study. The second core, L14-02, was taken on a yedoma hill about $1 \mathrm{~km}$ west of the Zimov'e River mouth. The entire core was $20.0 \mathrm{~m}$ long, including wedge ice below $10.9 \mathrm{mb}$.s. Five sediment samples from the top to a depth of $10.9 \mathrm{~m}$ b.s. (32.2-21.3 m a.s.1.) were incubated for the current study. 
Table 1. Compilation of the regional chronostratigraphy of the Laptev Sea region used in this work with paleoclimate (summer) and vegetation history based on an overview by Andreev et al. (2011) and references therein.

\begin{tabular}{lllll}
\hline Age (ka BP) & Period & $\begin{array}{l}\text { Regional } \\
\text { chronos- } \\
\text { tratigraphy }\end{array}$ & $\begin{array}{l}\text { Marine } \\
\text { Isotope } \\
\text { Stage } \\
\text { (MIS) }\end{array}$ & Regional climate and vegetation \\
\hline$<10.3$ & Holocene & Holocene & MIS 1 & $\begin{array}{l}\text { Climate amelioration during the early } \\
\text { Holocene; shrub-tundra vegetation } \\
\text { gradually disappeared ca 7.6 ka BP. }\end{array}$ \\
\hline ca 10.3-13 & $\begin{array}{l}\text { Late glacial-early } \\
\text { Holocene transition }\end{array}$ & & & $\begin{array}{l}\text { Climate amelioration after the Last } \\
\text { Glacial Maximum; transition to } \\
\text { shrubby tundra vegetation. }\end{array}$ \\
\hline ca. 13-30 & $\begin{array}{l}\text { Late Weichselian } \\
\text { glacial (stadial) }\end{array}$ & Sartan & MIS 2 & $\begin{array}{l}\text { Cold and dry summer conditions, win- } \\
\text { ter colder than today; open tundra } \\
\text { steppe. }\end{array}$ \\
\hline ca. 30-55 & $\begin{array}{l}\text { Middle Weichselian } \\
\text { glacial (interstadial) }\end{array}$ & Kargin & MIS 3 & $\begin{array}{l}\text { Relatively warm and wet summers; } \\
\text { open herb- and shrub-dominated vege- } \\
\text { tation. }\end{array}$ \\
\hline
\end{tabular}

\section{Methods}

\subsection{Geochemical characteristics}

Gravimetric water contents were calculated as the weight difference between wet and dried $\left(105^{\circ} \mathrm{C}\right)$ samples. $\mathrm{pH}$ values were measured in a suspension of $5 \mathrm{~g}$ thawed sediment in $12.5 \mathrm{~mL}$ distilled water (CG820, Schott AG, Mainz, Germany). For sediment chemical analyses, bulk samples were dried at $70^{\circ} \mathrm{C}$ and milled. Total carbon (TC) and total nitrogen (TN) contents were measured with an element analyzer (VarioMAX cube, Elementar Analysensysteme $\mathrm{GmbH}$, Hanau, Germany), while TOC contents were measured with a liquiTOC II coupled to a solids module (Elementar Analysensysteme $\mathrm{GmbH}$, Hanau, Germany). The $\delta^{13} \mathrm{C}_{\text {org }}$ values were measured with an isotope-ratio mass spectrometer (Delta V, Thermo Scientific, Dreieich, Germany) coupled to an elemental analyzer (Flash 2000, Thermo Scientific, Dreieich, Germany) after samples were treated with phosphoric acid to release inorganic carbon.

\subsection{Incubation}

Frozen samples were slowly thawed from -18 to $4{ }^{\circ} \mathrm{C}$ over $48 \mathrm{~h}$ in a refrigerator, homogenized and divided into triplicates. Anaerobic incubations were prepared under a nitrogen atmosphere in a glove box. Approximately 15-30 g thawed sediment was weighed into glass bottles and sealed with rubber stoppers. Anaerobic samples were saturated with 5-20 mL of nitrogen-flushed, $\mathrm{CO}_{2}$-free distilled water, and the headspace was exchanged with molecular nitrogen. The headspace of aerobic incubation bottles was exchanged with synthetic air (20\% oxygen, $80 \%$ nitrogen). We added enough molecular nitrogen and synthetic air to establish a slight overpressure inside each bottle. In occasional cases of negative pressure differences between headspace pressure and ambient pressure, we added 5-10 mL of molecular nitrogen to reestablish overpressure.

Samples from all three study locations were incubated for 134 days at $4{ }^{\circ} \mathrm{C}$. During this time, the headspace $\mathrm{CO}_{2}$ and $\mathrm{CH}_{4}$ concentrations were measured weekly to biweekly. The incubation of samples from the Buor Khaya Peninsula and Bol'shoy Lyakhovsky Island continued for 785 days and the gas concentrations were measured every 8-12 weeks. To determine the gas concentrations inside each bottle, $1 \mathrm{~mL}$ of headspace gas was removed by a syringe and injected into a gas chromatograph (GC 7890 Agilent Technologies, Santa Clara, USA) equipped with a $500 \mu \mathrm{L}$ sample loop, a nickel catalyst to reduce $\mathrm{CO}_{2}$ to $\mathrm{CH}_{4}$, and a flame ionizing detector (FID). Gases were separated on a PorapakQ column with helium as carrier gas. If the headspace concentration of $\mathrm{CO}_{2}$ in aerobic incubation bottles approached $3 \%$, the headspace was again exchanged with synthetic air.

The amount of gas in the headspace was calculated from the concentration in the headspace, headspace volume, incubation temperature, and pressure inside the bottle using the ideal gas law. The amount of gas dissolved in water was calculated from the gas concentration in the headspace, pressure inside the bottle, water content, $\mathrm{pH}$, and gas solubility. Solubility for $\mathrm{CO}_{2}$ and $\mathrm{CH}_{4}$ in water at $4{ }^{\circ} \mathrm{C}$ was calculated after Carroll et al. (1991) and Yamamoto et al. (1976), respectively. To account for the dissociation of carbonic acid in water at different $\mathrm{pH}$ values, we used dissociation constants from Millero et al. (2007). 

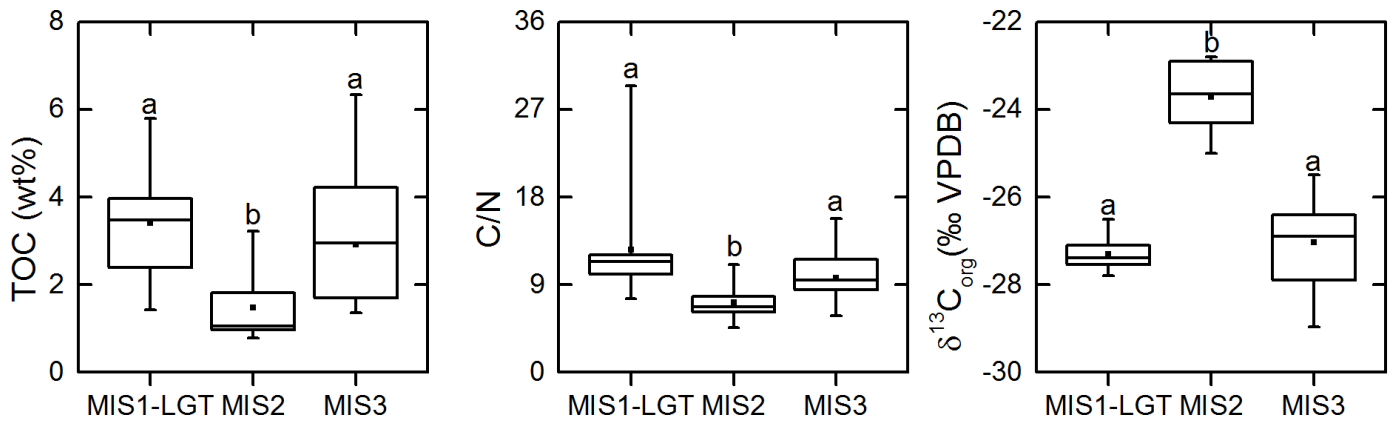

Figure 2. Box plot of total organic carbon (TOC), total organic carbon to total nitrogen ratio (C / N), and $\delta^{13} \mathrm{C}_{\text {org }}$ values of permafrost deposits from the MUO12 sequence, the BK8 core, and the two L14 cores from the Holocene interglacial (MIS 1), including the late glacial transition (LGT) $(n=12)$, the Sartan stadial (MIS 2) $(n=6)$, and the Kargin interstadial (MIS 3) $(n=27)$. The whiskers show the data range and the box indicates the interquartile range. The vertical line and square inside the boxes show the median and mean, respectively. The letters above the whiskers indicate statistically significant differences in geochemical characteristics between the deposits of different ages (Mann-Whitney test, $p<0.016$ for TOC and $\mathrm{C} / \mathrm{N}, p<0.001$ for $\delta^{13} \mathrm{C}_{\mathrm{org}}$ ).

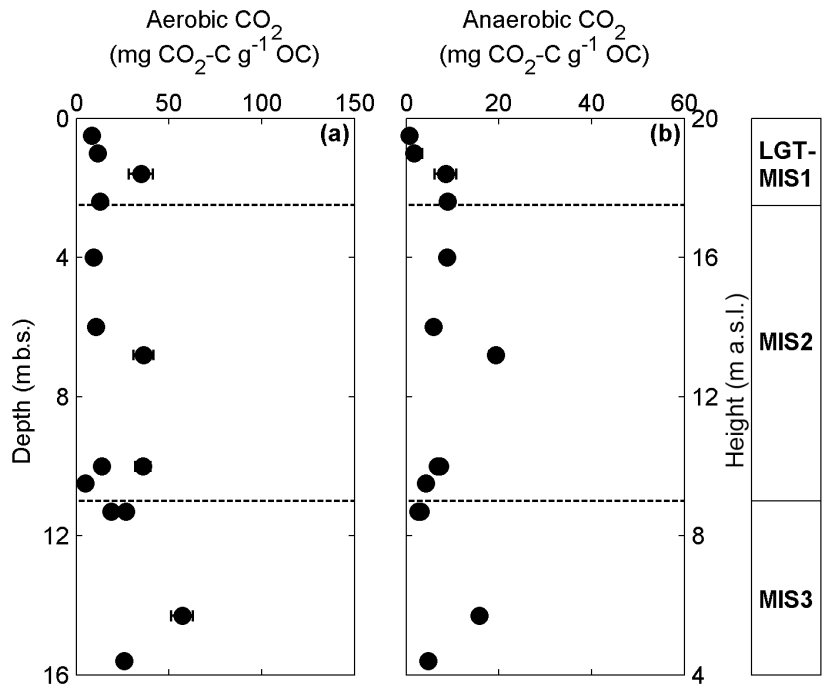

Figure 3. Depth profiles of total aerobic (a) and anaerobic (b) $\mathrm{CO}_{2}$ production per gram of organic carbon $\left(\mathrm{g}^{-1} \mathrm{OC}\right)$ in sediment samples from the MUO12 sequence after 134 incubation days at $4{ }^{\circ} \mathrm{C}$ for deposits from the Holocene interglacial (MIS 1), including the late glacial transition (LGT), the Sartan stadial (MIS 2), and the Kargin interstadial (MIS 3). Data are mean values $(n=3)$ and error bars represent 1 standard deviation. Note the different scales. No $\mathrm{CH}_{4}$ production was observed during the 134-day incubation period.

\subsection{Statistics}

Differences in mean values were analyzed with the KruskalWallis test followed by multiple post hoc Mann-Whitney tests with the Bonferroni adjustment for multiple group comparisons. We tested for differences between deposits from different periods as well as for differences between deposits from the same period but from different locations. In both cases, the number of post hoc comparisons was three, giving an adjusted significance level of 0.017. All statistical analyses were performed using MATLAB ${ }^{\circledR}$ (MATLAB and Statistics Toolbox Release 2015b, The MathWorks Inc., Natick, MA, USA).

\section{Results}

\subsection{Chronostratigraphy and geochemical characteristics}

The sedimentary sequence on Muostakh Island was divided into three sections, which were separated by two erosional contacts and sharply intersecting ice wedges (Meyer et al., 2015). Based on radiocarbon ages (Meyer et al., unpublished data), these sections could be separated into three periods (Fig. 3). Deposits from the uppermost section between 0.5 and $2.4 \mathrm{~m}$ b.s. were classified as Holocene deposits from the MIS 1 and deposits from the late glacial to early Holocene transition, confirmed by radiocarbon ages of 7.5 and $13.2 \mathrm{ka} \mathrm{BP}$ for samples at 1.3 and $2.4 \mathrm{~m}$ b.s., respectively. The middle section between 4 and $10 \mathrm{~m}$ b.s. yielded radiocarbon ages of 16.1-18.9 ka BP and were therefore classified as Sartan stadial deposits from the MIS 2. The lowermost section, between 11.3 and $15.6 \mathrm{~m}$ b.s., yielded radiocarbon ages of 41.6-45.9 ka BP and represents the MIS 3 Kargin interstadial.

The BK8 core from the Buor Khaya Peninsula was subdivided into four sections (Fig. 4). The first section, between 0 and $0.5 \mathrm{~m}$ b.s., represents the seasonally thawed active layer. The subdivision of the permafrost deposits below the active layer was based on previously published radiocarbon and infrared-stimulated luminescence (IRSL) ages (Schirrmeister et al., 2017). Deposits from the second section, between 0.5 and $3.2 \mathrm{~m}$ b.s., yielded radiocarbon ages between 9.7 and $11.4 \mathrm{kaBP}$, which corresponds to the late glacial transition to the early Holocene. The third section, between 3.2 and 

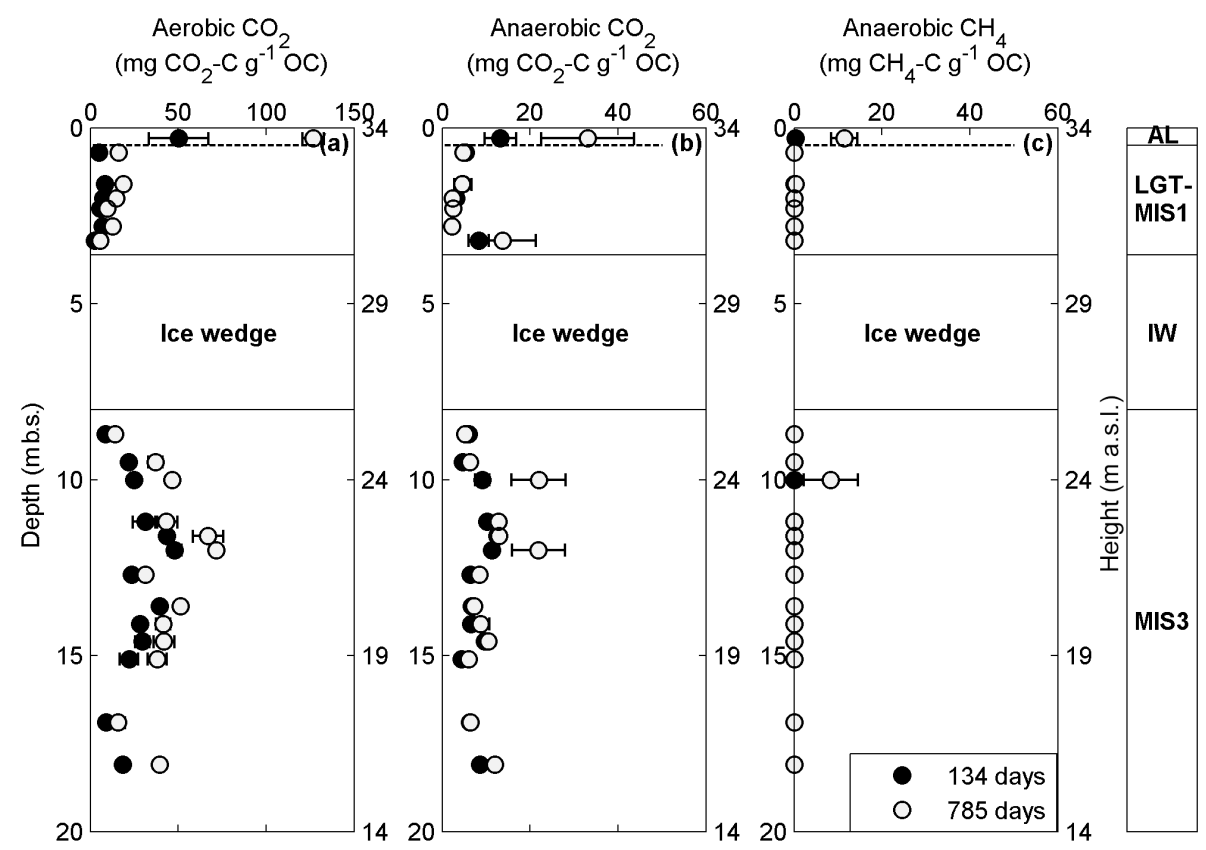

Figure 4. Depth profiles of total aerobic $\mathrm{CO}_{2}(\mathbf{a})$, anaerobic $\mathrm{CO}_{2}(\mathbf{b})$, and anaerobic $\mathrm{CH}_{4}$ (c) production per gram of organic carbon ( $\mathrm{g}^{-1} \mathrm{OC}$ ) in sediment samples from the BK8 core after 134 (closed symbols) and 785 (open symbols) incubation days at $4{ }^{\circ} \mathrm{C}$ for the active layer (AL), which is considered to be $0.5 \mathrm{~m}$ thick, and permafrost deposits from the Holocene interglacial (MIS 1), including the late glacial transition (LGT) and the Kargin interstadial (MIS 3). Data are mean values $(n=3)$ and error bars represent 1 standard deviation. Note the different scales.

$8.5 \mathrm{~m}$ b.s., consisted of an ice wedge, which was not sampled for the current study. The fourth section, between 8.5 and $18.9 \mathrm{~m}$ b.s., yielded infinite radiocarbon ages older than $50 \mathrm{ka} \mathrm{BP}$. The additional IRSL ages of feldspar grains yielded deposition ages of about $45 \mathrm{ka}$ BP. Thus, sediments from this section were classified as deposits from the Kargin interstadial.

The upper $0.5 \mathrm{~m}$ from both cores from Bol'shoy Lyakhovsky Island represent the active layer. Radiocarbon ages of the L14-05 core from the thermokarst basin ranged between 2.2 and $10.1 \mathrm{kaBP}$ for the upper core section between $0-1.7 \mathrm{mb}$.s. and $51.2-54.6 \mathrm{ka} \mathrm{BP}$ for deposits below $5.8 \mathrm{~m}$ b.s. (Zimmermann et al., 2017a). Based on these ages, stratigraphic interpretations from a nearby outcrop (Wetterich et al., 2009), and the available palynological data (Zimmermann et al., 2017a), the L14-05 core was divided into two parts (Fig. 5). The upper part, between 0 and $5.5 \mathrm{~m}$ b.s., was deposited during the Holocene and late glacial transition, while deposits below $5.5 \mathrm{~m}$ b.s. originate from the Kargin interstadial. Deposits from the L14-02 core from the yedoma hill yielded radiocarbon ages between 33.1 and $62.8 \mathrm{kaBP}$, which corresponds to deposition during the MIS 3 Kargin interstadial.

Overall, the permafrost deposits showed a wide range in TOC contents, $\mathrm{C} / \mathrm{N}$, and $\delta^{13} \mathrm{C}_{\text {org }}$ (Fig. 2). Generally higher TOC contents and $\mathrm{C} / \mathrm{N}$ were found in deposits from the Holocene and Kargin interstadial than in deposits from the
Sartan stadial (Mann-Whitney test, $p<0.017$ ), while the $\delta^{13} \mathrm{C}_{\text {org }}$ values were significantly higher in Sartan stadial deposits (Mann-Whitney test, $p<0.001$ ).

\subsection{Greenhouse gas production potentials}

\subsubsection{Muostakh Island}

Based on the TOC content, $\mathrm{CO}_{2}$ production after 134 incubation days from sediment samples from the MUO12 sequence ranged between 4.8 and $60.7 \mathrm{mg} \mathrm{CO}_{2}-\mathrm{Cg}^{-1} \mathrm{OC}$ under aerobic conditions and between 0.5 and $20.9 \mathrm{mg} \mathrm{CO}_{2}-\mathrm{Cg}^{-1} \mathrm{OC}$ under anaerobic conditions (Fig. 3). Higher aerobic $\mathrm{CO}_{2}$ production was generally observed in the lowermost Kargin deposits between 11.3 and $15.6 \mathrm{~m}$ b.s. (Table 2), but elevated $\mathrm{CO}_{2}$ production was also observed at $1.6,6$, and $10 \mathrm{mb}$.s. Under anaerobic conditions, the highest production was observed at $6 \mathrm{~m}$ b.s., which was nearly twice as high as in most other samples. No methanogenesis was observed in any $\mathrm{Mu}-$ ostakh Island samples over the 134-day incubation period.

\subsubsection{Buor Khaya Peninsula}

After 134 incubation days, $\mathrm{CO}_{2}$ production in $\mathrm{BK} 8$ core samples ranged between 2.2 and $64.1 \mathrm{mg} \mathrm{CO}_{2}-\mathrm{C} \mathrm{g}^{-1} \mathrm{OC}$ aerobically and between 2.2 and $17.1 \mathrm{mg} \mathrm{CO}_{2}-\mathrm{Cg}^{-1} \mathrm{OC}$ anaerobically (Fig. 4), which is within the same range as production in samples from Muostakh Island over the same incubation 


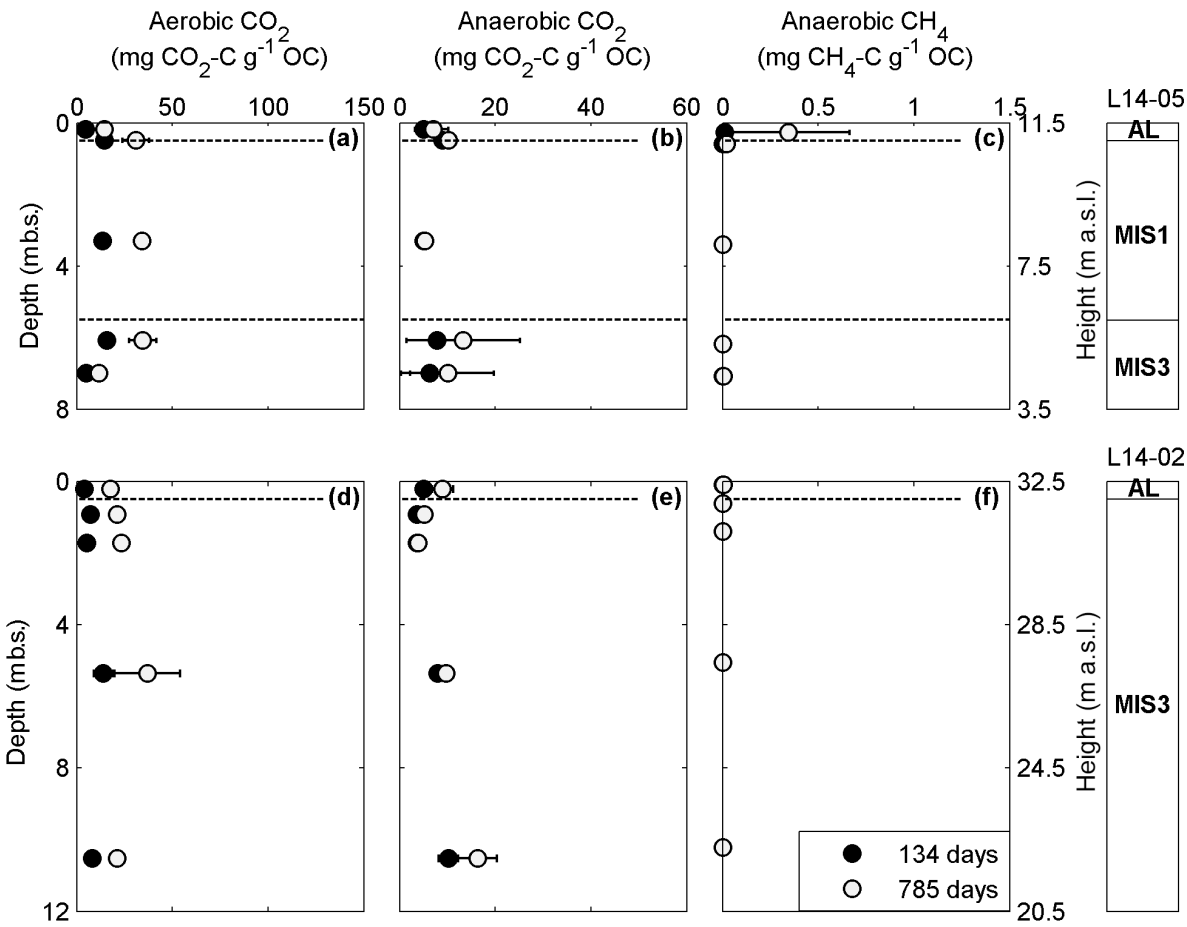

Figure 5. Depth profiles of total aerobic $\mathrm{CO}_{2}(\mathbf{a})$, anaerobic $\mathrm{CO}_{2}(\mathbf{b})$, and anaerobic $\mathrm{CH}_{4}(\mathbf{c})$ production per gram of organic carbon $\left(\mathrm{g}^{-1} \mathrm{OC}\right)$ in sediment samples from the L14-05 (a-c), and L14-02 cores (d-f) after 134 (closed symbols) and 785 (open symbols) incubation days at $4{ }^{\circ} \mathrm{C}$ for the active layer (AL), which is considered to be $0.5 \mathrm{~m}$ thick, and permafrost deposits from the Holocene interglacial (MIS 1) and the Kargin interstadial (MIS 3). Data are mean values $(n=3)$ and error bars represent 1 standard deviation. Note the different scales.

Table 2. Mean ( \pm 1 standard deviation) $\mathrm{CO}_{2}$ and $\mathrm{CH}_{4}$ production after 134 and 785 incubation days. Production after 785 days was not determined (n.d.) for the Muostakh Island sequence. MIS 2 deposits were not present in the sample material from the Buor Khaya Peninsula and Bol'shoy Lyakhovsky Island.

\begin{tabular}{|c|c|c|c|c|c|c|c|c|}
\hline \multirow[t]{2}{*}{$\begin{array}{l}\text { Location } \\
\text { (sample } \\
\text { code) }\end{array}$} & \multirow[t]{2}{*}{$\begin{array}{l}\text { Marine } \\
\text { Isotope } \\
\text { Stage (MIS) }\end{array}$} & \multirow[t]{2}{*}{$n$} & \multicolumn{2}{|c|}{$\begin{array}{c}\text { Aerobic } \mathrm{CO}_{2} \\
\text { production } \\
\left(\mathrm{mg} \mathrm{CO} 2-\mathrm{Cg}^{-1} \mathrm{OC}\right)\end{array}$} & \multicolumn{2}{|c|}{$\begin{array}{c}\text { Anaerobic } \mathrm{CO}_{2} \\
\text { production } \\
\left(\mathrm{mg} \mathrm{CO}-\mathrm{Cg}^{-1} \mathrm{OC}\right)\end{array}$} & \multicolumn{2}{|c|}{$\begin{array}{c}\text { Anaerobic } \mathrm{CH}_{4} \\
\text { production } \\
\left(\mathrm{mg} \mathrm{CH}_{4}-\mathrm{Cg}^{-1} \mathrm{OC}\right)\end{array}$} \\
\hline & & & 134 days & 785 days & 134 days & 785 days & 134 days & 785 days \\
\hline \multirow{4}{*}{$\begin{array}{l}\text { Muostakh } \\
\text { Island } \\
\text { (MUO12) }\end{array}$} & Active layer & \multicolumn{7}{|c|}{ Not sampled } \\
\hline & MIS 1 & 12 & $17.0 \pm 11.9$ & n.d. & $4.9 \pm 4.2$ & n.d. & 0 & n.d. \\
\hline & MIS 2 & 17 & $17.4 \pm 12.9$ & n.d. & $8.8 \pm 5.2$ & n.d. & 0 & n.d. \\
\hline & MIS 3 & 12 & $32.2 \pm 15.6$ & n.d. & $6.6 \pm 5.6$ & n.d. & 0 & n.d. \\
\hline \multirow{4}{*}{$\begin{array}{l}\text { Buor Khaya } \\
\text { Peninsula } \\
(\mathrm{BK} 8)\end{array}$} & Active layer & 3 & $50.2 \pm 16.9$ & $126.8 \pm 6.0$ & $13.3 \pm 3.5$ & $33.1 \pm 10.6$ & $0.4 \pm 0.2$ & $11.4 \pm 3.0$ \\
\hline & MIS 1-LGT & 15 & $6.1 \pm 1.8$ & $13.4 \pm 4.5$ & $4.1 \pm 2.2$ & $4.5 \pm 4.1$ & 0 & 0 \\
\hline & MIS 2 & \multicolumn{7}{|c|}{ Not present in the core material } \\
\hline & MIS 3 & 38 & $27.2 \pm 11.7$ & $42.2 \pm 15.9$ & $7.9 \pm 2.5$ & $11.0 \pm 5.8$ & 0 & $0.4 \pm 2.1 *$ \\
\hline Bol'shoy & Active layer & 6 & $4.3 \pm 0.6$ & $15.9 \pm 2.8$ & $5.0 \pm 1.3$ & $8.0 \pm 2.7$ & 0 & $0.2 \pm 0.3^{*}$ \\
\hline Lyakhovsky & MIS 1-LGT & 6 & $13.8 \pm 2.4$ & $32.6 \pm 4.8$ & $6.9 \pm 2.3$ & $7.8 \pm 2.9$ & 0 & 0 \\
\hline Island & MIS 2 & \multicolumn{7}{|c|}{ Not present in the core material } \\
\hline (L14) & MIS 3 & 18 & $9.2 \pm 4.7$ & $24.7 \pm 11.1$ & $6.6 \pm 2.9$ & $9.7 \pm 7.0$ & 0 & 0 \\
\hline
\end{tabular}

* Methanogenesis was only observed in two replicates.

period (Table 2). The highest production was observed in the active layer. Production then decreased sharply by between 0.5 and $3.2 \mathrm{~m}$ b.s. but increased again in Kargin interstadial deposits below the ice wedge. Methanogenesis was only observed in the active layer, but in much smaller quantities than anaerobic $\mathrm{CO}_{2}$ production. 

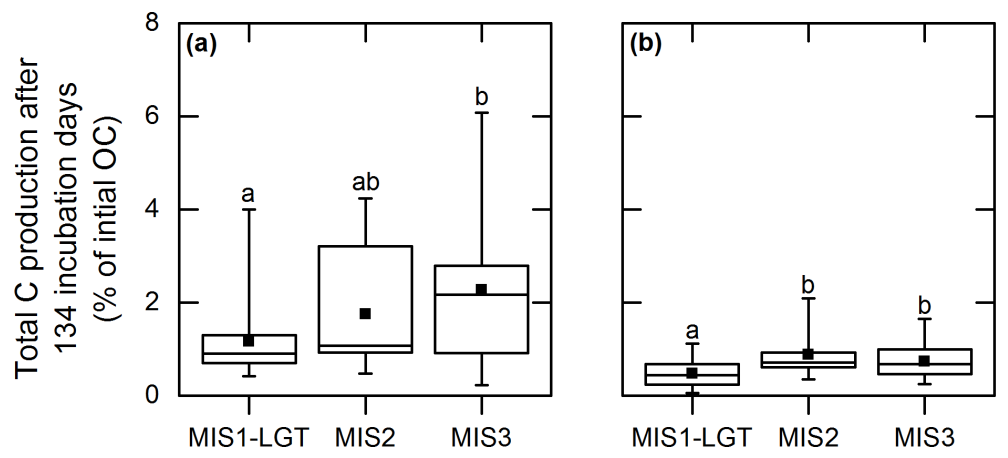

Figure 6. Total aerobic (a) and anaerobic (b) $\mathrm{CO}_{2}-\mathrm{C}$ production after 134 incubation days from permafrost deposits from the MUO12 sequence, the BK8 core, and the two L14 cores from the Holocene interglacial (MIS 1), including the late glacial transition (LGT) ( $n=22$ ), the Sartan stadial (MIS 2) $(n=15)$, and the Kargin interstadial (MIS 3) $(n=50)$. The whiskers show the data range and the box indicates the interquartile range. The vertical line and square inside the boxes show the median and mean, respectively. The different letters indicate significant differences (Mann-Whitney test, $p<0.016$ ) between deposits from different periods.

To assess the decomposability of OC over longer periods, all BK8 core samples were incubated for a total of 785 days. After 785 incubation days, $\mathrm{CO}_{2}$ production ranged between 4.6 and $131.1 \mathrm{mg} \mathrm{CO}_{2}-\mathrm{Cg}^{-1} \mathrm{OC}$ under aerobic conditions and between 2.2 and $43.0 \mathrm{mg} \mathrm{CO}_{2}-\mathrm{Cg}^{-1} \mathrm{OC}$ under anaerobic conditions. $\mathrm{CO}_{2}$ production rates, however, decreased sharply within the first weeks of incubation. On average, $58 \% \pm 12 \%$ of the aerobically and $86 \% \pm 24 \%$ of the anaerobically produced $\mathrm{CO}_{2}$ after 785 incubation days was already produced within the first 134 days. In contrast, $\mathrm{CH}_{4}$ production in the active layer increased 30-fold between 134 and 785 incubation days. Additionally, two out of three replicates at $10 \mathrm{~m}$ b.s. also showed active methanogenesis between 134 and 785 days. The total $\mathrm{CH}_{4}$ production after 785 days accounted for 17 and $50 \%$ of the total carbon production in those samples, respectively.

\subsubsection{Bol'shoy Lyakhovsky Island}

Aerobic $\mathrm{CO}_{2}$ production after 134 incubation days in samples from the $\mathrm{L} 14$ cores ranged between 3.7 and $18.9 \mathrm{mg} \mathrm{CO}_{2}-\mathrm{Cg}^{-1} \mathrm{OC}$ (Fig. 5). The mean aerobic $\mathrm{CO}_{2}$ production in all MIS 3 Kargin interstadial deposits from Bol'shoy Lyakhovsky Island was significantly lower (MannWhitney test, $p<0.001)$ than $\mathrm{CO}_{2}$ production in MIS 3 deposits from Muostakh Island and the Buor Khaya Peninsula (Table 2). Anaerobic $\mathrm{CO}_{2}$ production in Kargin deposits from Bol'shoy Lyakhosvky Island ranged between 3.2 and $11.6 \mathrm{mg} \mathrm{CO}_{2}-\mathrm{C} \mathrm{g}^{-1} \mathrm{OC}$, which was within the same range as production observed from the other two locations. No $\mathrm{CH}_{4}$ production was observed in any L14 samples after 134 days.

After 785 incubation days, aerobic and anaerobic $\mathrm{CO}_{2}$ production ranged between 11.0 and $55.2 \mathrm{mg} \mathrm{CO}_{2}-\mathrm{C} \mathrm{g}^{-1} \mathrm{OC}$ and between 3.0 and $27.0 \mathrm{mg} \mathrm{CO}_{2}-\mathrm{Cg}^{-1} \mathrm{OC}$, respectively. Active methanogenesis was only observed in two out of three replicates from the active layer from the L14-05 core. However, $\mathrm{CH}_{4}$ production was an order of magnitude lower than anaerobic $\mathrm{CO}_{2}$ production in the same sample and also an order of magnitude smaller than $\mathrm{CH}_{4}$ production in the active layer from the Buor Khaya Peninsula.

\subsection{Decomposability of permafrost $\mathrm{OM}$ deposited under different climatic regimes}

Overall, permafrost OM deposited during the MIS 3 Kargin interstadial supported the highest greenhouse gas production (Fig. 6). After 134 days of aerobic incubation, $0.2 \%$ $6.1 \%$ of the initially available $\mathrm{OC}$ was decomposed to $\mathrm{CO}_{2}$. This was significantly more (Mann-Whitney test, $p<0.001$ ) than in deposits from the Holocene and late glacial transition, where production ranged between $0.4 \%$ and $4.0 \%$. The aerobic $\mathrm{CO}_{2}$ production in MIS 2 Sartan stadial deposits ranged between $0.5 \%$ and $4.2 \%$. Anaerobically, 3.3 times less $\mathrm{CO}_{2}$ was produced (Pearson correlation coefficient $r=0.63, p<0.001$ ). The lowest production was observed in Holocene and late glacial transition deposits, where $0.1 \%$ $1.1 \%$ of the $\mathrm{OC}$ was anaerobically decomposed to $\mathrm{CO}_{2}$. This was significantly less (Mann-Whitney test, $p<0.01$ ) than in yedoma deposits, where $0.4 \%-2.1 \%$ and $0.2 \%-1.6 \%$ of initial OC were decomposed in Sartan stadial and Kargin interstadial deposits, respectively.

\section{Discussion}

\subsection{Organic matter decomposability}

The ice-rich permafrost deposits of Muostakh Island, the Buor Khaya Peninsula, and Bol'shoy Lyakhovsky Island are typical for northeastern Siberia, and the geochemical OM characteristics (TOC, $\mathrm{C} / \mathrm{N}, \delta^{13} \mathrm{C}_{\mathrm{org}}$ ) were all within the range of other permafrost deposits in the region (Schirrmeister et al., 2011). However, a better understanding of the differences in OM decomposability is needed to estimate 
the contribution of thawing permafrost landscapes to future greenhouse gas fluxes.

The highest $\mathrm{CO}_{2}$ production potentials from permafrost samples in the BK8 core were observed below the ice wedge between 8.35 and $16 \mathrm{~m}$ b.s. (Fig. 3). For this core section, which was deposited during the MIS 3 Kargin interstadial (Schirrmeister et al., 2017), Zimmermann et al. (2017b) report a high taxonomic richness of vascular plants with high proportions of swamp and aquatic taxa, pointing towards a water-saturated environment at the time of deposition, likely a low-centered ice-wedge polygon. Furthermore, Stapel et al. (2016) report high concentrations of branched glycerol dialkyl glycerol tetraether (br-GDGT), a microbial membrane compound, at 10, 11.2, and $15 \mathrm{mb}$ b.s., indicative of a soil microbial community, which developed when the climate was relatively warm and wet. Together with higher TOC contents at these depths, this suggests accumulation of relatively undecomposed OM under anaerobic conditions, which can be quickly decomposed after thaw (de Klerk et al., 2011), resulting in higher $\mathrm{CO}_{2}$ production. In contrast, a lower abundance of swamp taxa and higher abundance of terrestrial taxa at $8.8 \mathrm{~m}$ b.s. and below $15 \mathrm{~m}$ b.s. (Zimmermann et al., 2017b), suggest that intermittently drier conditions existed. This resulted in accelerated OM decomposition under aerobic conditions prior to $\mathrm{OM}$ incorporation into the permafrost and therefore lower TOC contents as well as lower $\mathrm{CO}_{2}$ production potentials at these depths, as observed in this study.

Sediments above the ice wedge in the BK8 core showed similar TOC contents, $\mathrm{C} / \mathrm{N}$, and $\delta^{13} \mathrm{C}_{\mathrm{org}}$ values compared to the rest of the core, but $\mathrm{CO}_{2}$ production was consistently low in this section. This $\sim 3 \mathrm{~m}$ long core section yielded radiocarbon ages of 11.4-10.1 ka BP (Schirrmeister et al., 2017), which corresponds to the late glacial-early Holocene transition. After the Last Glacial Maximum (LGM), temperatures were favorable for the increased microbial decomposition of active layer OM, which led to the preservation of comparatively stable OM fractions after the material was incorporated into the permafrost. If these sediments were to thaw again in the future, results from the current study suggest that the decomposability of the remaining OM will be comparatively low. However, deeper rooting, cryoturbation, and postthaw leaching of labile OM from vegetation could stimulate the decomposition and greenhouse gas production from more stable OM through positive priming (Fontaine et al., 2007). Both the chemical structure (Di Lonardo et al., 2017) and the frequency of labile OM inputs (Fan et al., 2013) influence the size of the priming effect. For permafrost soils, it has also been shown that the priming effect is larger at lower temperatures (Walz et al., 2017). Thus, climatic conditions influence the vegetation composition and OM source on a regional level, but the local depositional environment as well as postdepositional processes likely also control the amount and decomposability of the OM that is presently incorporated in permafrost.
The first results of in situ $\mathrm{CO}_{2}$ fluxes from Muostakh Island were published by Vonk et al. (2012). Based on the downslope decrease in OC contents, they estimate that $66 \%$ of the thawed yedoma $\mathrm{OC}$ can be decomposed to $\mathrm{CO}_{2}$ and released back to the atmosphere before the material is reburied in the Laptev Sea. This is an order of magnitude more than what the results from current incubation study suggest, where after 134 days only $0.4 \%-6.0 \%$ of the yedoma OC from Muostakh Island were aerobically decomposed to $\mathrm{CO}_{2}$. No further detailed palynological or microbial biomarker studies are yet available for the MUO12 sequence. The closest reference location is the comprehensive permafrost record at the Mamontovy Khayata section on the Bykovsky Peninsula (Andreev et al., 2002; Sher et al., 2005). Between 58 and $12 \mathrm{ka} \mathrm{BP}$ (Schirrmeister et al., 2002b), fine-grained material accumulated on the large flat foreland plain of the presentday Bykovsky Peninsula area that was exposed at a time of lower sea level (Grosse et al., 2007). Sea level rise after the last glacial period, coastal erosion, and marine ingression of thermokarst basins formed the Buor Khaya Bay and eventually separated Muostakh Island from the Bykovsky Peninsula (Grosse et al., 2007; Romanovskii et al., 2004). It is likely that the deposition regimes on Muostakh Island and the Buor Khaya Peninsula were similar to the regime at the Bykovsky Peninsula. This conclusion is also supported by similar OM decomposability. After 134 incubation days, the amount of aerobic and anaerobic $\mathrm{CO}_{2}$ production did not differ significantly (Mann-Whitney test, $p=0.339$ ) between MIS 3 Kargin deposits from Muostakh Island and the Buor Khaya Peninsula (Table 2), which suggests that the deposits formed under similar conditions. In contrast, aerobic $\mathrm{CO}_{2}$ production in MIS 3 deposits from Bol'shoy Lyakhovsky Island in the eastern Laptev Sea was nearly 3 times lower than that observed for Muostakh Island and the Buor Khaya Peninsula in the central Laptev Sea. Considerably lower temperatures and precipitation characterize the current climate on Bol'shoy Lyakhovsky Island. It is also likely that regional differences between the eastern and central Laptev Sea region would have affected the paleoclimate (Anderson and Lozhkin, 2001; Lozhkin and Anderson, 2011; Wetterich et al., 2011, 2014). Different summer temperatures, precipitation, thaw depth, and vegetation composition could explain regional differences in OM quantity and decomposability.

A distinctive feature of the Muostakh Island sequence is the preservation of MIS 2 Sartan deposits, which are only sparsely preserved in northeastern Siberia (Wetterich et al., 2011). Interestingly, mean aerobic $\mathrm{CO}_{2}$ production in Sartan deposits from Muostakh Island was lower than in Kargin deposits, but slightly higher under anaerobic conditions, but the difference was not statistically significant (MannWhitney test, $p=0.205$ ). The rapid deposition of $8 \mathrm{~m}$ thick comparatively coarse-grained material in just a few thousand years between 20 and $16 \mathrm{ka} \mathrm{BP}$ were unfavorable for the development of a stable land surface and the establishment of a vegetation cover comparable to the Kargin interstadial or 
Holocene (Meyer et al., unpublished data). Pollen analyses from the corresponding sections on the Bykovsky Peninsula (Andreev et al., 2002) and Kurungnakh Island in the Lena River delta (Schirrmeister et al., 2008; Wetterich et al., 2008) suggest relatively cold and dry summer conditions during this stadial with sparse vegetation. Relatively undecomposed OM was quickly buried, before it could be transformed to greenhouse gases.

\subsection{Multiannual incubation}

The 785-day incubation of permafrost samples from the Buor Khaya Peninsula and Bol'shoy Lyakhovsky Island revealed that $51 \%$ of the aerobically and $83 \%$ of the anaerobically produced $\mathrm{CO}_{2}$ was already produced within the first 134 incubation days, highlighting the nonlinearity of OM decomposition dynamics (Knoblauch et al., 2013; Schädel et al., 2014) and the importance of the labile OC pool in short-term incubations. Maximum $\mathrm{CO}_{2}$ production rates were generally reached within the first 100 incubation days. After the initial peak, $\mathrm{CO}_{2}$ production rates remained consistently low (median $23.3 \mu \mathrm{g} \mathrm{CO}_{2}-\mathrm{Cg}^{-1} \mathrm{OC} \mathrm{d}^{-1}$ aerobically and $3.2 \mu \mathrm{g} \mathrm{CO}_{2}$ $\mathrm{Cg}^{-1} \mathrm{OCd}^{-1}$ anaerobically). These rates are within the range of other multiannual production rates from yedoma deposits in northeastern Siberia (Dutta et al., 2006; Knoblauch et al., 2013) and Alaska (Lee et al., 2012).

Assuming no new input of labile OM (e.g., from the current vegetation), decomposition rates are likely to remain low after the labile pool is depleted. Short-term greenhouse gas production and release from thawing ice-rich permafrost will therefore mainly depend on the size of the labile pool. A synthesis study of several incubation studies from highlatitude soils, including yedoma deposits, estimated the size of the labile OC pool to be generally less than $5 \%$ of the TOC (Schädel et al., 2014). For yedoma deposits on nearby Kurungnakh Island in the Lena River delta, Knoblauch et al. (2013) estimated the size of the labile pool to be even smaller (less than $2 \%$ ). Considering the large slowly decomposing permafrost OC pool (Schädel et al., 2014), long-term decomposition rates are therefore likely to provide more reliable projections of future greenhouse gas production in degrading permafrost landscapes.

\subsection{Methanogenesis}

$\mathrm{CH}_{4}$ production from yedoma deposits, or the lack thereof, is a highly controversial topic in permafrost research (Rivkina et al., 1998; Treat et al., 2015; Knoblauch et al., 2018). In the current work, active methanogenesis was only observed in 2 out of 38 yedoma samples from the BK8 core. In those samples showing active methanogenesis, $\mathrm{CH}_{4}$ production continued to rise over the 785 incubation days, which is in contrast to anaerobic $\mathrm{CO}_{2}$ production, which decreased with increasing incubation time. Rising $\mathrm{CH}_{4}$ production rates indicate that methanogenic communities still grow in these samples and were not limited by substrate supply. Chemical pore water and bulk sediment analyses from the BK8 core showed that there are high concentrations of both free and OMbound acetate present in yedoma deposits, indicating a high substrate potential for methanogenesis (Stapel et al., 2016). Knoblauch et al. (2018) showed that the small contribution of methanogenesis to overall anaerobic permafrost OM decomposition found in short-term incubation studies (Treat et al., 2015 ) is due to the absence of an active methanogenic community. On a multiannual timescale, methanogenic communities become active and equal amounts of $\mathrm{CO}_{2}$ and $\mathrm{CH}_{4}$ are produced from permafrost $\mathrm{OM}$ under anaerobic conditions. Under future climate warming and renewed thermokarst activity, high levels of $\mathrm{CH}_{4}$ production can be expected locally, but depend on favorable conditions such as above-zero temperatures and anaerobic conditions. It can be expected that the development of an active methanogenic community, e.g., by growth or downward migration of modern methanogenic organisms, will lead to elevated long-term $\mathrm{CH}_{4}$ production in these deposits (Knoblauch et al., 2018).

\section{Conclusion}

In this study, we investigated greenhouse gas production potential in degrading ice-rich permafrost deposits from three locations in northeastern Siberia. We hypothesized that the climatic conditions during deposition affected the amount and decomposability of preserved $\mathrm{OM}$ and thus greenhouse gas production potential after thawing. OM decomposability therefore needs to be interpreted against the paleoenvironmental background. It could be shown that yedoma deposits generally contained more labile OM than Holocene deposits. However, in addition to the regional climate conditions at the time of OM deposition, local depositional environments also influenced the amount and decomposability of the preserved fossil OM. Within the deposits of the MIS 3 Kargin interstadial, sediments deposited under wet and possibly anaerobic conditions produced more $\mathrm{CO}_{2}$ than sediments deposited under drier aerobic conditions. Further, deposits from the central Laptev Sea region produced 2-3 times more $\mathrm{CO}_{2}$ than deposits from the eastern Laptev Sea region. It is therefore likely that OM decomposability of the vast yedoma landscape cannot be generalized solely based on the stratigraphic position. Furthermore, it is expected that $\mathrm{CH}_{4}$ production will play a more prominent role after active methanogenic communities have established, since abundant substrates for methanogenesis were present.

Data availability. All data sets shown as well as the temporal evolution of $\mathrm{CO}_{2}$ and $\mathrm{CH}_{4}$ production over the whole incubation period are available at https://doi.pangaea.de/10.1594/PANGAEA. 892950 (last access: 13 August 2018; Walz et al., 2018). 
Author contributions. JW and CK designed the study. TO collected sediment samples on Muostakh Island and LS collected cores from the Buor Khaya Peninsula and Bol'shoy Lyakhovsky Island. JW and RT performed the laboratory analyses, with guidance from CK and EMP. JW performed data analyses and wrote the paper with contributions from all authors.

Competing interests. The authors declare that they have no conflict of interest.

Acknowledgements. This research was supported by the German Ministry of Education and Research as part of the projects CarboPerm (grant no. 03G0836A, 03G0836B) and KoPf (grant no. 03F0764A). We further acknowledge the financial support through the German Research Foundation (DFG) to EMP and CK through the Cluster of Excellence "CliSAP" (EXC177), University of Hamburg, and to Thomas Opel (grant OP 217/3-1). We also thank the Russian and German participants of the drilling and sampling expeditions, especially Mikhail N. Grigoriev (Melnikov Permafrost Institute, Yakutsk), Hanno Meyer, and Pier Paul Overduin (both Alfred-Wegener-Institute, Potsdam). Additional thanks go to Georg Schwamborn (Alfred-Wegener-Institute, Potsdam) for his assistance with core subsampling and Birgit Schwinge (Institute of Soil Science, Hamburg) for her help in the laboratory. We are also immensely grateful for the two anonymous reviews on a previous version of this paper.

Edited by: Alexey V. Eliseev

Reviewed by: two anonymous referees

\section{References}

Anderson, P. M. and Lozhkin, A. V.: The Stage 3 interstadial complex (Karginskii/middle Wisconsinan interval) of Beringia: variations in paleoenvironments and implications for paleoclimatic interpretations, Quaternary Sci. Rev., 20, 93-125, https://doi.org/10.1016/S0277-3791(00)00129-3, 2001.

Andreev, A. A., Schirrmeister, L., Siegert, C., Bobrov, A. A., Demske, D., Seiffert, M., and Hubberten, H.-W.: Paleoenvironmental changes in northeastern Siberia during the Late Quaternary - Evidence from pollen records of the Bykovsky Peninsula, Polarforschung, 70, 13-25, 2002.

Andreev, A. A., Grosse, G., Schirrmeister, L., Kuznetsova, T. V., Kuzmina, S. A., Bobrov, A. A., Tarasov, P. E., Novenko, E. Y., Meyer, H., Derevyagin, A. Y., Kienast, F., Bryantseva, A., and Kunitsky, V. V.: Weichselian and Holocene palaeoenvironmental history of the Bol'shoy Lyakhovsky Island, New Siberian Archipelago, Arctic Siberia, Boreas, 38, 72-110, https://doi.org/10.1111/j.1502-3885.2008.00039.x, 2009.

Andreev, A. A., Schirrmeister, L., Tarasov, P. E., Ganopolski, A., Brovkin, V., Siegert, C., Wetterich, S., and Hubberten, H.-W.: Vegetation and climate history in the Laptev Sea region (Arctic Siberia) during Late Quaternary inferred from pollen records, Quaternary Sci. Rev., 30, 2182-2199, https://doi.org/10.1016/j.quascirev.2010.12.026, 2011.
Brown, J., Ferrians Jr, O. J., Heginbottom, J. A., and Melnikov, E. S.: Circum-Arctic map of permafrost and ground-ice conditions, National Snow and Ice Data Center/World Data Center for Glaciology, Digit. media, Boulder, CO, USA, available at: http://nsidc.org/data/GGD318 (last access: 8 October 2014), 1998.

Bulygina, O. N. and Razuvaev, V. N.: Daily temperature and precipitation data for 518 Russian meteorological stations, Carbon Dioxide Information Analysis Center, Oak Ridge National Laboratory, U.S. Department of Energy, Oak Ridge, Tennessee, USA, 2012.

Carroll, J. J., Slupsky, J. D., and Mather, A. E.: The solubility of carbon dioxide in water at low pressure, J. Phys. Chem. Ref. Data, 20, 1201, https://doi.org/10.1063/1.555900, 1991.

CAVM Team: Circumpolar Arctic Vegetation Map (1:7500 000 scale), Conservation of Arctic Flora and Fauna (CAFF) Map No. 1, U.S. Fish and Wildlife Service, Anchorage, Alaska, USA, 2003.

de Klerk, P., Donner, N., Karpov, N. S., Minke, M., and Joosten, H.: Short-term dynamics of a low-centred ice-wedge polygon near Chokurdakh (NE Yakutia, NE Siberia) and climate change during the last ca 1250 years, Quaternary Sci. Rev., 30, 3013-3031, https://doi.org/10.1016/j.quascirev.2011.06.016, 2011.

Di Lonardo, D. P., De Boer, W., Klein Gunnewiek, P. J. A., Hannula, S. E. and Van der Wal, A.: Priming of soil organic matter: Chemical structure of added compounds is more important than the energy content, Soil Biol. Biochem., 108, 41-54, https://doi.org/10.1016/j.soilbio.2017.01.017, 2017.

Drozdov, D. S., Rivkin, F. M., Rachold, V., Ananjeva-Malkova, G. V., Ivanova, N. V., Chehina, I. V., Koreisha, M. M., Korostelev, Y. V., and Melnikov, E. S.: Electronic atlas of the Russian Arctic coastal zone, Geo-Mar. Lett., 25, 81-88, https://doi.org/10.1007/s00367-004-0189-7, 2005.

Dutta, K., Schuur, E. A. G., Neff, J. C., and Zimov, S. A.: Potential carbon release from permafrost soils of Northeastern Siberia, Glob. Change Biol., 12, 2336-2351, https://doi.org/10.1111/j.1365-2486.2006.01259.x, 2006.

Fan, Z., Jastrow, J. D., Liang, C., Matamala, R., and Miller, R. M.: Priming effects in boreal black spruce forest soils: Quantitative evaluation and sensitivity analysis, PLoS One, 8, e77880, https://doi.org/10.1371/journal.pone.0077880, 2013.

Fontaine, S., Barot, S., Barré, P., Bdioui, N., Mary, B., and Rumpel, C.: Stability of organic carbon in deep soil layers controlled by fresh carbon supply, Nature, 450, 277-280, https://doi.org/10.1038/nature06275, 2007.

Grigoriev, M. N., Overduin, P. P., Schirrmeister, L., and Wetterich, S.: Scientific permafrost drilling campaign, in Russian-German cooperation SYSTEM LAPTEV SEA?: The Expeditions Laptev Sea - Mamontov Klyk 2011 \& Buor Khaya 2012, edited by: Günther, F., Overduin, P. P., Makarov, A. S., and Grigoriev, M. N., Reports on Polar and Marine Research, 664, 75-86, 2013.

Grosse, G., Schirrmeister, L., Siegert, C., Kunitsky, V. V., Slagoda, E. A., Andreev, A. A., and Dereviagyn, A. Y.: Geological and geomorphological evolution of a sedimentary periglacial landscape in Northeast Siberia during the Late Quaternary, Geomorphology, 86, 25-51, https://doi.org/10.1016/j.geomorph.2006.08.005, 2007.

Grosse, G., Robinson, J. E., Bryant, R., Taylor, M. D., Harper, W., DeMasi, A., Kyker-Snowman, E., Veremeeva, A., Schirrmeis- 
ter, L. and Harden, J.: Distribution of late Pleistocene ice-rich syngenetic permafrost of the Yedoma Suite in east and central Siberia, Russia, Geol. Surv. Open File Rep., 1078, 1-37, available at: http://epic.awi.de/33878/ (last access: 3 April 2017), 2013.

Günther, F., Overduin, P. P., Sandakov, A. V., Grosse, G., and Grigoriev, M. N.: Short- and long-term thermo-erosion of ice-rich permafrost coasts in the Laptev Sea region, Biogeosciences, 10, 4297-4318, https://doi.org/10.5194/bg-10-4297-2013, 2013.

Günther, F., Overduin, P. P., Yakshina, I. A., Opel, T., Baranskaya, A. V., and Grigoriev, M. N.: Observing Muostakh disappear: permafrost thaw subsidence and erosion of a ground-ice-rich island in response to arctic summer warming and sea ice reduction, The Cryosphere, 9, 151-178, https://doi.org/10.5194/tc-9-151-2015, 2015.

Harden, J. W., Koven, C. D., Ping, C.-L., Hugelius, G., David McGuire, A., Camill, P., Jorgenson, T., Kuhry, P., Michaelson, G. J., O’Donnell, J. A., Schuur, E. A. G., Tarnocai, C., Johnson, K., and Grosse, G.: Field information links permafrost carbon to physical vulnerabilities of thawing, Geophys. Res. Lett., 39, 1-6, https://doi.org/10.1029/2012GL051958, 2012.

Hugelius, G., Routh, J., Kuhry, P., and Crill, P.: Mapping the degree of decomposition and thaw remobilization potential of soil organic matter in discontinuous permafrost terrain, J. Geophys. Res.-Biogeo., 117, G02030, https://doi.org/10.1029/2011JG001873, 2012.

Hugelius, G., Strauss, J., Zubrzycki, S., Harden, J. W., Schuur, E. A. G., Ping, C.-L., Schirrmeister, L., Grosse, G., Michaelson, G. J., Koven, C. D., O’Donnell, J. A., Elberling, B., Mishra, U., Camill, P., Yu, Z., Palmtag, J., and Kuhry, P.: Estimated stocks of circumpolar permafrost carbon with quantified uncertainty ranges and identified data gaps, Biogeosciences, 11, 6573-6593, https://doi.org/10.5194/bg-11-6573-2014, 2014.

Iversen, C. M., Sloan, V. L., Sullivan, P. F., Euskirchen, E. S., McGuire, A. D., Norby, R. J., Walker, A. P., Warren, J. M., and Wullschleger, S. D.: The unseen iceberg: Plant roots in arctic tundra, New Phytol., 205, 34-58, https://doi.org/10.1111/nph.13003, 2015.

Kanevskiy, M., Shur, Y., Fortier, D., Jorgenson, M. T., and Stephani, E.: Cryostratigraphy of late Pleistocene syngenetic permafrost (yedoma) in northern Alaska, Itkillik River exposure, Quaternary Res., 75, 584-596, https://doi.org/10.1016/j.yqres.2010.12.003, 2011.

Knoblauch, C., Beer, C., Sosnin, A., Wagner, D., and Pfeiffer, E.-M.: Predicting long-term carbon mineralization and trace gas production from thawing permafrost of Northeast Siberia, Glob. Change Biol., 19, 1160-1172, https://doi.org/10.1111/gcb.12116, 2013.

Knoblauch, C., Beer, C., Liebner, S., Grigoriev, M. N., and Pfeiffer, E.-M.: Methane production as key to the greenhouse gas budget of thawing permafrost, Nat. Clim. Change, 8, 309-312, https://doi.org/10.1038/s41558-018-0095-z, 2018.

Lee, H., Schuur, E. A. G., Inglett, K. S., Lavoie, M., and Chanton, J. P.: The rate of permafrost carbon release under aerobic and anaerobic conditions and its potential effects on climate, Glob. Change Biol., 18, 515-527, https://doi.org/10.1111/j.13652486.2011.02519.x, 2012.

Lozhkin, A. V. and Anderson, P. M.: Forest or no forest: Implications of the vegetation record for climatic stability in Western
Beringia during oxygen isotope stage 3, Quaternary Sci. Rev., 30, 2160-2181, https://doi.org/10.1016/j.quascirev.2010.12.022, 2011.

MacDougall, A. H. and Knutti, R.: Projecting the release of carbon from permafrost soils using a perturbed parameter ensemble modelling approach, Biogeosciences, 13, 2123-2136, https://doi.org/10.5194/bg-13-2123-2016, 2016.

Meyer, H., Opel, T., and Dereviagin, A.: Stratigraphic and sedimentological studies, in Russian-German Cooperation SYSTEM LAPTEV SEA: The expedition Lena 2012, Reports on Polar and Marine Research, 79-82, 2015.

Millero, F., Huang, F., Graham, T., and Pierrot, D.: The dissociation of carbonic acid in $\mathrm{NaCl}$ solutions as a function of concentration and temperature, Geochim. Cosmochim. Ac., 71, 46-55, https://doi.org/10.1016/j.gca.2006.08.041, 2007.

Morgenstern, A., Ulrich, M., Günther, F., Roessler, S., Fedorova, I. V., Rudaya, N. A., Wetterich, S., Boike, J., and Schirrmeister, L.: Evolution of thermokarst in East Siberian icerich permafrost: A case study, Geomorphology, 201, 363-379, https://doi.org/10.1016/j.geomorph.2013.07.011, 2013.

Natali, S. M., Schuur, E. A. G., Mauritz, M., Schade, J. D., Celis, G., Crummer, K. G., Johnston, C., Krapek, J., Pegoraro, E., Salmon, V. G., and Webb, E. E.: Permafrost thaw and soil moisture driving $\mathrm{CO}_{2}$ and $\mathrm{CH}_{4}$ release from upland tundra, J. Geophys. Res.Biogeo., 120, 525-537, https://doi.org/10.1002/2014JG002872, 2015.

Opel, T., Wetterich, S., Meyer, H., Dereviagin, A. Y., Fuchs, M. C., and Schirrmeister, L.: Ground-ice stable isotopes and cryostratigraphy reflect late Quaternary palaeoclimate in the Northeast Siberian Arctic (Oyogos Yar coast, Dmitry Laptev Strait), Clim. Past, 13, 587-611, https://doi.org/10.5194/cp-13587-2017, 2017.

Overduin, P. P., Liebner, S., Knoblauch, C., Günther, F., Wetterich, S., Schirrmeister, L., Hubberten, H.-W., and Grigoriev, M. N.: Methane oxidation following submarine permafrost degradation: Measurements from a central Laptev Sea shelf borehole, J. Geophys. Res.-Biogeo., 120, 1-14, https://doi.org/10.1002/2014JG002862, 2015.

Ping, C. L., Jastrow, J. D., Jorgenson, M. T., Michaelson, G. J., and Shur, Y. L.: Permafrost soils and carbon cycling, SOIL, 1, 147171, https://doi.org/10.5194/soil-1-147-2015, 2015.

Rivkina, E., Gilichinsky, D., Wagener, S., Tiedje, J., and McGrath, J.: Biogeochemical activity of anaerobic microorganisms from buried permafrost sediments, Geomicrobiol. J., 15, 187-193, https://doi.org/10.1080/01490459809378075, 1998.

Romanovskii, N. N., Hubberten, H.-W., Gavrilov, A. V., Tumskoy, V. E., and Kholodov, A. L.: Permafrost of the east Siberian Arctic shelf and coastal lowlands, Quaternary Sci. Rev., 23, 1359-1369, https://doi.org/10.1016/j.quascirev.2003.12.014, 2004.

Schädel, C., Schuur, E. A. G., Bracho, R., Elberling, B., Knoblauch, C., Lee, H., Luo, Y., Shaver, G. R. and Turetsky, M. R.: Circumpolar assessment of permafrost $\mathrm{C}$ quality and its vulnerability over time using long-term incubation data, Glob. Change Biol., 20 641-652, https://doi.org/10.1111/gcb.12417, 2014.

Schirrmeister, L., Oezen, D., and Geyh, M. A.: ${ }^{230} \mathrm{Th} / \mathrm{U}$ dating of frozen peat, Bol'shoy Lyakhovsky Island (Northern Siberia), Quaternary Res., 57, 253-258, https://doi.org/10.1006/qres.2001.2306, 2002a. 
Schirrmeister, L., Siegert, C., Kuznetsova, T., Kuzmina, S., Andreev, A., Kienast, F., Meyer, H., and Bobrov, A.: Paleoenvironmental and paleoclimatic records from permafrost deposits in the Arctic region of Northern Siberia, Quatern. Int., 89, 97-118, https://doi.org/10.1016/S1040-6182(01)00083-0, 2002b.

Schirrmeister, L., Grosse, G., Kunitsky, V., Magens, D., Meyer, H., Dereviagin, A., Kuznetsova, T., Andreev, A., Babiy, O., Kienast, F., Grigoriev, M., Overduin, P. P., and Preusser, F.: Periglacial landscape evolution and environmental changes of Arctic lowland areas for the last 60000 years (western Laptev Sea coast, Cape Mamontov Klyk), Polar Res., 27, 249-272, https://doi.org/10.1111/j.1751-8369.2008.00067.x, 2008.

Schirrmeister, L., Kunitsky, V., Grosse, G., Wetterich, S., Meyer, H., Schwamborn, G., Babiy, O., Derevyagin, A., and Siegert, C.: Sedimentary characteristics and origin of the Late Pleistocene Ice Complex on north-east Siberian Arctic coastal lowlands and islands - A review, Quatern. Int., 241, 3-25, https://doi.org/10.1016/j.quaint.2010.04.004, 2011.

Schirrmeister, L., Froese, D., Tumskoy, V., Grosse, G., and Wetterich, S.: Yedoma: Late Pleistocene ice-rich syngenetic permafrost of Beringia, in: Encyclopedia of Quaternary Science, edited by: Elias, S. A., Elsevier, Amsterdam, the Netherlands, 542-552, 2013.

Schirrmeister, L., Schwamborn, G., Overduin, P. P., Strauss, J., Fuchs, M. C., Grigoriev, M., Yakshina, I., Rethemeyer, J., Dietze, E., and Wetterich, S.: Yedoma Ice Complex of the Buor Khaya Peninsula (southern Laptev Sea), Biogeosciences, 14, 1261-1283, https://doi.org/10.5194/bg-14-1261-2017, 2017.

Schneider von Deimling, T., Meinshausen, M., Levermann, A., Huber, V., Frieler, K., Lawrence, D. M., and Brovkin, V.: Estimating the near-surface permafrost-carbon feedback on global warming, Biogeosciences, 9, 649-665, https://doi.org/10.5194/bg-9649-2012, 2012.

Schneider von Deimling, T., Grosse, G., Strauss, J., Schirrmeister, L., Morgenstern, A., Schaphoff, S., Meinshausen, M., and Boike, J.: Observation-based modelling of permafrost carbon fluxes with accounting for deep carbon deposits and thermokarst activity, Biogeosciences, 12, 3469-3488, https://doi.org/10.5194/bg12-3469-2015, 2015.

Schuur, E. A. G., McGuire, A. D., Schädel, C., Grosse, G., Harden, J. W., Hayes, D. J., Hugelius, G., Koven, C. D., Kuhry, P., Lawrence, D. M., Natali, S. M., Olefeldt, D., Romanovsky, V. E., Schaefer, K., Turetsky, M. R., Treat, C. C., and Vonk, J. E.: Climate change and the permafrost carbon feedback, Nature, 520, 171-179, https://doi.org/10.1038/nature14338, 2015.

Schwamborn, G. and Schirrmeister, L.: Permafrost drilling on Bol'shoy Lyakhovsky, in Russian-German Cooperation CARBOPERM: Field campaigns to Bol'shoy Lyakhovsky Island in 2014, 11-19, 2015.

Sher, A. V., Kuzmina, S. A., Kuznetsova, T. V., and Sulerzhitsky, L. D.: New insights into the Weichselian environment and climate of the East Siberian Arctic, derived from fossil insects, plants, and mammals, Quaternary Sci. Rev., 24, 533-569, https://doi.org/10.1016/j.quascirev.2004.09.007, 2005.

Shmelev, D., Veremeeva, A., Kraev, G., Kholodov, A., Spencer, R. G. M., Walker, W. S., and Rivkina, E.: Estimation and sensitivity of carbon storage in permafrost of north-eastern Yakutia, Permafrost Periglac., 28, 379-390, https://doi.org/10.1002/ppp.1933, 2017.
Stapel, J. G., Schirrmeister, L., Overduin, P. P., Wetterich, S., Strauss, J., Horsfield, B., and Mangelsdorf, K.: Microbial lipid signatures and substrate potential of organic matter in permafrost deposits: Implications for future greenhouse gas production, J. Geophys. Res.-Biogeo., 121, 2652-2666, https://doi.org/10.1002/2016JG003483, 2016.

Stapel, J. G., Schwamborn, G., Schirrmeister, L., Horsfield, B., and Mangelsdorf, K.: Substrate potential of last interglacial to Holocene permafrost organic matter for future microbial greenhouse gas production, Biogeosciences, 15, 1969-1985, https://doi.org/10.5194/bg-15-1969-2018, 2018.

Strauss, J., Schirrmeister, L., Grosse, G., Wetterich, S., U1rich, M., Herzschuh, U., and Hubberten, H.-W.: The deep permafrost carbon pool of the Yedoma region in Siberia and Alaska, Geophys. Res. Lett., 40, 6165-6170, https://doi.org/10.1002/2013GL058088, 2013.

Strauss, J., Schirrmeister, L., Mangelsdorf, K., Eichhorn, L., Wetterich, S., and Herzschuh, U.: Organic-matter quality of deep permafrost carbon - a study from Arctic Siberia, Biogeosciences, 12, 2227-2245, https://doi.org/10.5194/bg-12-2227-2015, 2015.

Strauss, J., Schirrmeister, L., Grosse, G., Fortier, D., Hugelius, G., Knoblauch, C., Romanovsky, V., Schädel, C., Schneider von Deimling, T., Schuur, E. A. G., Shmelev, D., Ulrich, M., and Veremeeva, A.: Deep Yedoma permafrost: A synthesis of depositional characteristics and carbon vulnerability, Earth-Sci. Rev., 172, 75-86, https://doi.org/10.1016/j.earscirev.2017.07.007, 2017.

Treat, C. C., Natali, S. M., Ernakovich, J., Iversen, C. M., Lupascu, M., McGuire, A. D., Norby, R. J., Roy Chowdhury, T., Richter, A., Šantrůčková, H., Schädel, C., Schuur, E. A. G., Sloan, V. L., Turetsky, M. R., and Waldrop, M. P.: A pan-Arctic synthesis of $\mathrm{CH}_{4}$ and $\mathrm{CO}_{2}$ production from anoxic soil incubations, Glob. Change Biol., 21, 2787-2803, https://doi.org/10.1111/gcb.12875, 2015.

Ulrich, M., Grosse, G., Strauss, J., and Schirrmeister, L.: Quantifying wedge-ice volumes in Yedoma and thermokarst Basin deposits, Permafrost Periglac., 25, 151-161, https://doi.org/10.1002/ppp.1810, 2014.

van Everdingen, R.: Multi-language glossary of permafrost and related ground-ice terms, available at: https://globalcryospherewatch.org/reference/glossary_docs/ (last access: 1 January 2015), 2005.

Vonk, J. E., Sánchez-García, L., van Dongen, B. E., Alling, V., Kosmach, D., Charkin, A., Semiletov, I. P., Dudarev, O. V., Shakhova, N., Roos, P., Eglinton, T. I., Andersson, A., and Gustafsson, Ö.: Activation of old carbon by erosion of coastal and subsea permafrost in Arctic Siberia, Nature, 489, 137-140, https://doi.org/10.1038/nature11392, 2012.

Waldrop, M. P., Wickland, K. P., White Iii, R., Berhe, A. A., Harden, J. W., and Romanovsky, V. E.: Molecular investigations into a globally important carbon pool: Permafrost-protected carbon in Alaskan soils, Glob. Change Biol., 16, 2543-2554, https://doi.org/10.1111/j.1365-2486.2009.02141.x, 2010.

Walter Anthony, K. M., Zimov, S. A., Grosse, G., Jones, M. C., Anthony, P. M., Chapin III, F. S., Finlay, J. C., Mack, M. C., Davydov, S., Frenzel, P., and Frolking, S.: A shift of thermokarst lakes from carbon sources to sinks during the Holocene epoch, Nature, 511, 452-456, https://doi.org/10.1038/nature13560, 2014. 
Walz, J., Knoblauch, C., Böhme, L. and Pfeiffer, E.-M.: Regulation of soil organic matter decomposition in permafrost-affected Siberian tundra soils - Impact of oxygen availability, freezing and thawing, temperature, and labile organic matter, Soil Biol. Biochem., 110, 34-43, https://doi.org/10.1016/j.soilbio.2017.03.001, 2017.

Walz, J., Knoblauch, C., Tigges, R., Opel, T., Schirrmeister, L., and Pfeiffer, E.-M.: Incubation results from icerich permafrost deposits in Northeast Siberia, PANGAEA, https://doi.org/10.1594/PANGAEA.892950, 2018.

Weiss, N., Blok, D., Elberling, B., Hugelius, G., Jørgensen, C. J., Siewert, M. B., and Kuhry, P.: Thermokarst dynamics and soil organic matter characteristics controlling initial carbon release from permafrost soils in the Siberian Yedoma region, Sediment. Geol., 340, 38-48, https://doi.org/10.1016/j.sedgeo.2015.12.004, 2016.

Wetterich, S., Kuzmina, S., Andreev, A. A., Kienast, F., Meyer, H., Schirrmeister, L., Kuznetsova, T., and Sierralta, M.: Palaeoenvironmental dynamics inferred from late Quaternary permafrost deposits on Kurungnakh Island, Lena Delta, Northeast Siberia, Russia, Quaternary Sci. Rev., 27, 1523-1540, https://doi.org/10.1016/j.quascirev.2008.04.007, 2008.

Wetterich, S., Schirrmeister, L., Andreev, A. A., Pudenz, M., Plessen, B., Meyer, H., and Kunitsky, V. V.: Eemian and Late Glacial/Holocene palaeoenvironmental records from permafrost sequences at the Dmitry Laptev Strait (NE Siberia, Russia), Palaeogeogr. Palaeocl., 279, 73-95, https://doi.org/10.1016/j.palaeo.2009.05.002, 2009.

Wetterich, S., Rudaya, N., Tumskoy, V., Andreev, A. A., Opel, T., Schirrmeister, L., and Meyer, H.: Last Glacial Maximum records in permafrost of the East Siberian Arctic, Quaternary Sci. Rev., 30, 3139-3151, https://doi.org/10.1016/j.quascirev.2011.07.020, 2011.
Wetterich, S., Tumskoy, V., Rudaya, N., Andreev, A. A., Opel, T., Meyer, H., Schirrmeister, L., and Hüls, M.: Ice Complex formation in arctic East Siberia during the MIS 3 Interstadial, Quaternary Sci. Rev., 84, 39-55, https://doi.org/10.1016/j.quascirev.2013.11.009, 2014.

Wetterich, S., Tumskoy, V., Rudaya, N., Kuznetsov, V., Maksimov, F., Opel, T., Meyer, H., Andreev, A. A., and Schirrmeister, L.: Ice Complex permafrost of MIS5 age in the Dmitry Laptev Strait coastal region (East Siberian Arctic), Quaternary Sci. Rev., 147, 298-311, https://doi.org/10.1016/j.quascirev.2015.11.016, 2016.

Yamamoto, S., Alcauskas, J. B., and Crozier, T. E.: Solubility of methane in distilled water and seawater, J. Chem. Eng. Data, 21, 78-80, https://doi.org/10.1021/je60068a029, 1976.

Zimmermann, H., Raschke, E., Epp, L., Stoof-Leichsenring, K., Schirrmeister, L., Schwamborn, G., and Herzschuh, U.: The history of tree and shrub taxa on Bol'shoy Lyakhovsky Island (New Siberian Archipelago) since the last interglacial uncovered by sedimentary ancient DNA and pollen data, Genes-Basel, 8, 273, 28 pp., https://doi.org/10.3390/genes8100273, 2017 a.

Zimmermann, H. H., Raschke, E., Epp, L. S., Stoof-Leichsenring, K. R., Schwamborn, G., Schirrmeister, L., Overduin, P. P., and Herzschuh, U.: Sedimentary ancient DNA and pollen reveal the composition of plant organic matter in Late Quaternary permafrost sediments of the Buor Khaya Peninsula (north-eastern Siberia), Biogeosciences, 14, 575-596, https://doi.org/10.5194/bg-14-575-2017, 2017b.

Zimov, S. A., Davydov, S. P., Zimova, G. M., Davydova, A. I., Schuur, E. A. G., Dutta, K., and Chapin III, F. S.: Permafrost carbon: Stock and decomposability of a globally significant carbon pool, Geophys. Res. Lett., 33, L20502, https://doi.org/10.1029/2006GL027484, 2006. 